\title{
Osip macesnovih iglic, Meria laricis
}

\section{Nikica OGRIS $^{1^{*}}$, Zoran ZAVRTANIK ${ }^{2}$}

Poznamo tri povzročitelje osipa macesnovih iglic: Meria laricis Vuill., Mycosphaerella laricina R. Hartig in Hypodermella laricis Tub. Za točno določitev vzroka je potrebno mikroskopirati vzorce.

Osip macesnovih iglic, ki ga povzroča gliva Meria laricis, se je v letu 2008 pojavil v Baški grapi na večji površini $\mathrm{v}$ okolici Podbrda na evropskemu macesnu (Larix decidua Mill.). Gliva Meria laricis je dobro poznana bolezen sadik evropskega macesna iz gozdnih drevesnic (Jurc, 1986; Butin, 1995; Maček, 2008). Bolezen prepoznamo po tem, da se zgodaj poleti začnejo na iglicah pojavljati posamične rumenkaste pege (slika 1), s časom se število rumenih peg na iglicah povečuje, porumenele iglice ovenijo, rjavijo in predčasno odpadejo (slika 2). Pri sadikah evropskega macesna najprej odpadejo iglice na spodnjih vejah, kasneje pa še na vejah višje v krošnji. Večino iglic odpade takoj, nekaj jih ostane pritrjenih še dolgo časa (slika 2). $\mathrm{Na}$ predelu rumeno-rjave pege na iglici lahko s povečevalnim steklom opazimo skupine trosonoscev glive Meria laricis, ki izraščajo iz listnih rež iglice (slika 3). $\mathrm{Na}$ konidioforih se razvijajo enocelični, brezbarvni konidiji - nespolni trosi, ki so na sredini nekoliko zažeti in merijo $8-10 \times 2,5-3 \mu \mathrm{m}$. Gliva prezimi v odpadlih iglicah ali iglicah na drevesu, kjer spomladi oblikuje nove trose, s katerimi okuži nove mlade iglice. Japonski macesen (Larix kaempferi [Lamb.] Carr.) in hibridni macesen (Larix $x$ eurolepis Henry) sta odporna na omenjeno bolezen. Znano je, da je okužba z glivo Meria laricis intenzivnejša v bolj vlažnih razmerah. To je tudi zelo verjetno poglavitni razlog za obsežnejši pojav osipa macesnovih iglic zaradi opisane glive na območju Baške grape v letu 2008, saj je bilo poletje $\mathrm{v}$ 2008 nekoliko bolj vlažno od povprečja 1971-2000.

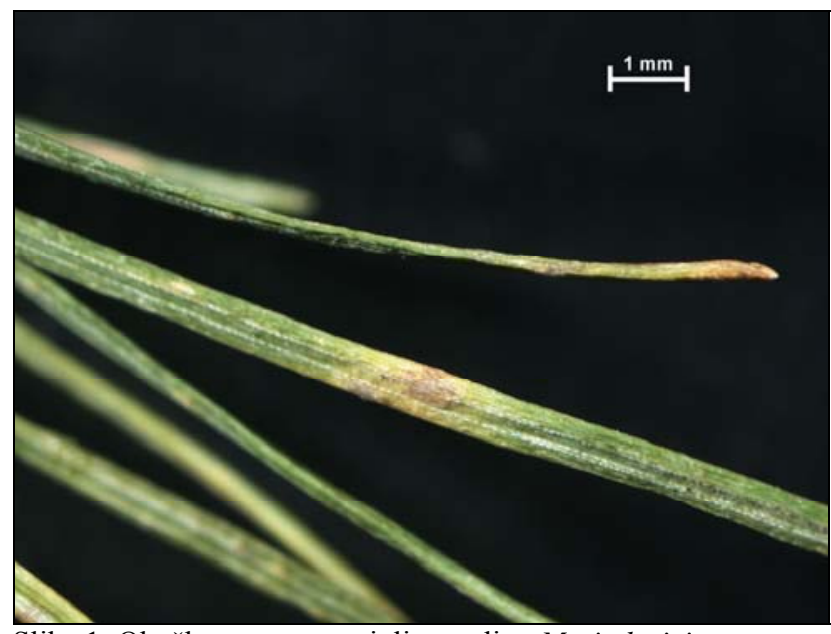

Slika 1: Okužba macesnove iglice $\mathrm{z}$ glivo Meria laricis
Kljub temu menimo, da je pojav osipa macesnovih iglic zaradi glive Meria laricis nenavaden, saj v Sloveniji še nimamo zabeleženo, da se bi ta bolezen pojavila izven gozdnih drevesnic $\mathrm{v}$ gozdovih na tako obsežni površini $\mathrm{z}$ veliko intenziteto. Bolezen se verjetno $\mathrm{v}$ Baški grapi pojavlja naravno, saj je prenos bolezni iz gozdne drevesnice izključen, ker se na tem območju macesen ni sadil že več let.

Osip macesnovih iglic je bolezen iglic, zato bo okužen macesen $\mathrm{v}$ letošnjem letu naslednjo pomlad normalno ozelenel. Če se osip macesnovih iglic pojavi le v enem letu, je zato nekoliko prizadet prirastek. Če pa se osip pojavlja zaporedoma več let, lahko resno oslabi drevo in ga tako naredi dovzetnejšega za druge sekundarne okužbe. V gozdu ne izvajamo ukrepov proti tej bolezni. Bolezen pa zatiramo v gozdnih drevesnicah s preventivnim škropljenjem s koloidnim žveplom ali kaptanom od začetka odpiranja brstov do sredine julija (Jurc, 1986).

\section{Viri}

Butin H. 1995. Tree diseases and disorders. Causes, biology and control in forest and amenity trees. Oxford University Press: 252 str. Jurc D. 1986. Osip macesnovih iglic v gozdni drevesnici Muta. Ljubljana, Inštitut za gozdno in lesno gospodarstvo pri BF: 3 str.

Maček J. 2008. Gozdna fitopatologija. Ljubljana, Zavod za gozdove Slovenije, Zveza gozdarskih društev Slovenije, Gozdarska založba: 448 str.

${ }^{1}$ Gozdarski inštitut Slovenije, Večna pot 2, 1000 Ljubljana; ${ }^{2 Z a v o d ~ z a ~ g o z d o-~}$ ve Slovenije, Območna enota Tolmin, Tumov drevored 17, 5220 Tolmin; *nikica.ogris@gozdis.si

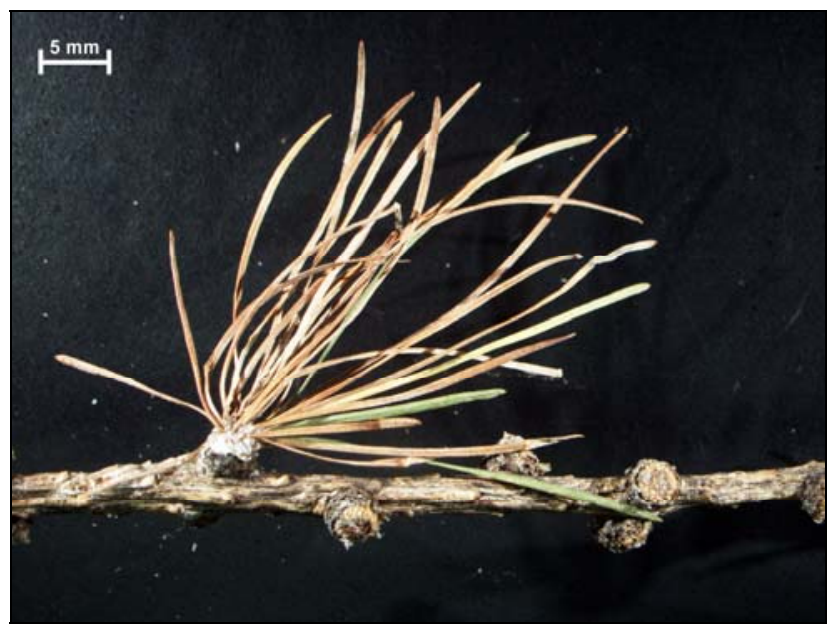

Slika 2: Porjavele iglice navadno odpadejo že zgodaj poleti, včasih pa ostanejo še pritrjene na kratkih poganjkih 


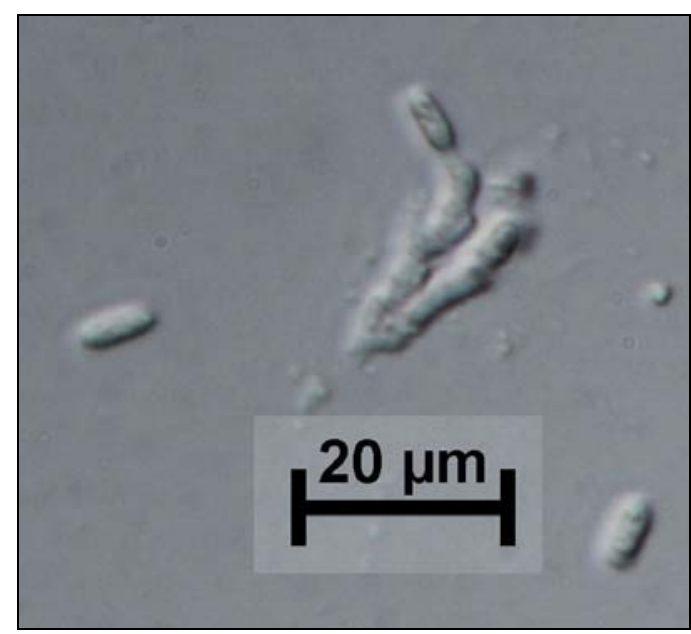

Slika 3: Trosonosci s konidiji glive Meria laricis

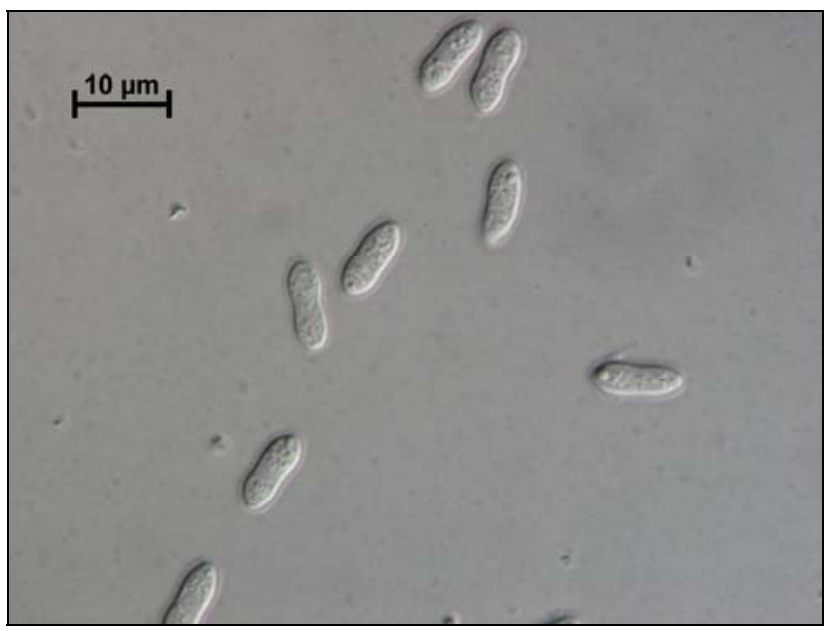

Slika 4: Brezbarvni konidiji glive Meria laricis

\section{Vzroki izredno obsežnega pojava sušice najmlajših borovih poganjkov (Diplodia pinea) v okolici Podgorja leta 2008}

\section{Nikica OGRIS $^{1^{*}}$, Boštjan KOŠIČEK ${ }^{2}$}

$\mathrm{Na}$ širšem območju Slavnika se je v letu 2008, na več sto hektarih gozda, pojavila sušica najmlajših borovih poganjkov na črnem boru (slika 1). Jakost bolezni je bila tako drastična, da se niso sušili samo najmlajši poganjki, ampak tudi veje in cela drevesa (slika 2). Zanimivo je prav to, da je bilo sušenje letošnjih ali lanskih poganjkov (slika 3) prej izjema kot pravilo, saj so v večini primerov odmrle cele veje in cela drevesa. Sušico najmlajših borovih poganjkov povzroča gliva Diplodia pinea (Desm.) J. Kickx f. (sinonim Sphaeropsis sapinea (Fr.) Dyko \& B. Sutton). Vsako leto povzroča na Krasu in drugod po Sloveniji večje ali manjše škode na borih. Raziskali smo domnevne vzroke, zakaj je v letu 2008 v Podgorju na Krasu povzročila tako veliko škodo.

Sušica najmlajših borovih poganjkov je dobro raziskana bolezen borov. Gliva Diplodia pinea je endofit, ki biva $\mathrm{v}$ zdravem tkivu in $\mathrm{v}$ normalnih okoliščinah borom ne povzroča nobene škode (Stanosz in sod., 1997) vendar postane patogena, kadar je rastlina v stresu. Diplodia pinea postane patogena v sušnem stresu (Stanosz in sod., 2001), po poškodbah zaradi toče (Smith in sod., 2002), po napadu žuželk (Feci in sod., 2003), ali pri pomanjkanju hranil. Večje poškodbe zaradi sušice najmlajših borovih poganjkov so zabeležili tudi v zaprtih dolinah ali zaprtih sestojih, kjer je višja relativna zračna vlažnost in so nihanja $v$ temperaturi zraka manjša (Zwolinski in sod., 1990). Črni bor (Pinus nigra Arn.) je načeloma odporen proti poletni suši in visokim temperaturam, ki se velikokrat pojavlja v mediteranskem območju. Vendar je zelo občutljiv na sušo $\mathrm{v}$ spomladanskih mesecih in na hitre spremembe temperature $\mathrm{v}$ času zime (Jankovsky in Palovčíková, 2003).

Povprečna letna količina padavin v obdobju 19712000 na območju Podgorja je bila 1552 mm. Najbližja padavinska postaja je Rakitovec, ki je od Podgorja oddaljena približno $6 \mathrm{~km}$. Iz slike 4 vidimo, da je bila povprečna letna količina padavin $\mathrm{v}$ Rakitovcu v obdobju 2000-2008 vsa leta podpovprečna z največjim primanjkljajem v letu 2003 in 2007 (ARSO, 2009). V letu 2007 je padlo $22 \%$ manj padavin kot povprečno. Iz podrobne analize količine padavin smo ugotovili, da je v letu 2007, eno leto pred obsežnim sušenjem črnega bora pri Podgorju, bistveno primanjkovalo padavin pomladi in poleti, v mesecih, ko je črni bor najbolj občutljiv na pomanjkanje padavin. Zima 2007/08 je bila nadpovprečno topla. Glede na podatke iz postaje Godnje je bila temperatura za $1,9{ }^{\circ} \mathrm{C}$ višja kot znaša dolgoletno povprečje. Povprečna letna temperatura pa je povprečje presegla za $2,0^{\circ} \mathrm{C}$, kar je enako kot leta 2003, ko je v Sloveniji pustošila suša. Pomlad 2007 je bila še posebej topla, saj je presegala dolgoletno povprečje za $3,3^{\circ} \mathrm{C}$. Predvsem nadpovprečno topla zima in pomlad v letu 2007 skupaj s pomanjkanjem padavin $\mathrm{v}$ istem času, so bili verjetno kritični za črni bor pri Podgorju. Menimo, da so prav takšne razmere pomenile zelo velik stres za črni bor in ga tako predisponirale za sušico najmlajših borovih poganjkov. Poleg tega so na postaji Rakitovec 30. aprila 2007 zabeležili točo, na postaji Podgrad pa še dve večji toči 23. maja 2007 in 27. septembra 2007. Toča je bila še dodatni stresni dejavnik, ki je na vejah in vejicah pustila poškodbe, t. j. odprte rane, katere je Diplodia pinea lažje okužila. Mikroklimatske razmere pri Podgorju ustrezajo zaprti dolini, ki jo z vseh strani obkrožajo višji hribi: Slavnik, Kojnik in Velike gorice. Vse naštete vremenske razmere (višje temperature, pomanjkanje padavin, toča) in orografske lastnosti pri Podgorju dovolj dobro pojasnjujejo izredno obsežne poškodbe zaradi glive Diplodia pinea v letu 2008 pri Podgorju. 